\title{
Article
}

\section{Preemption and Civic Democracy in the Battle over Wal-Mart}

\section{Catherine L. Fisk \& Michael M. Oswalt ${ }^{\dagger}$}

Where Wal-Mart goes, debate over the labor practices of the world's largest retailer seems inevitably to follow. While the company's expansion plans sometimes succeed and sometimes fail, the setting for these disputes rarely changes; the battle over Wal-Mart is fought primarily at the state and local levels. ${ }^{1}$ This battle pits activists committed to a "producerist" vision for the economy where workers are paid well, treated with respect, and have access to affordable health care ${ }^{2}$ against Wal-Mart's "consumerist" economic vision where low prices are the ultimate measure of societal well-being. ${ }^{3}$

The important debate over these two competing visions of social and economic welfare can occur in a truly democratic way only at the local level. There, however, the intensely democratic activism and civic dialogue generated by Wal-Mart and its opponents are severely constrained by the legal doctrine of

$\dagger \quad$ Ms. Fisk is the Douglas Blount Maggs Professor of Law at Duke University. Mr. Oswalt will receive a J.D. and an M.T.S. from Duke University in 2008. They gratefully acknowledge financial support for this project from the Fuller-Perdue Fund at Duke Law School. Copyright (C) 2008 by Catherine L. Fisk and Michael M. Oswalt.

1. See, e.g., Richard C. Schragger, The Anti-Chain Store Movement, Localist Ideology, and the Remnants of the Progressive Constitution, 1920-1940, 90 IOWA L. REV. 1011, 1090 (2005) (noting that the "battle" over Wal-Mart expansion must be fought at the local level); Jessica Garrison \& Sara Lin, WalMart vs. Inglewood a Warm-Up for L.A. Fight, L.A. TIMES, Apr. 2, 2004, at A1 (describing local efforts in several California communities to stop development of Wal-Mart Supercenters).

2. See Michael KAZIN, The Populist Persuasion 56, 162-63 (1995) (describing the producerist ethic as "labor creates all wealth" and that "power should be wielded at least as much by those who create wealth as by those who possess it").

3. See Schragger, supra note 1, at 1089 ("Wal-Mart is representative of an economy that has become obsessed with price competition to the detriment of other values."). 
preemption, which holds that the existence of a federal law on a topic can block state and local authorities from enacting laws on the same topic. ${ }^{4} \mathrm{~A}$ federal court ruling that state or local law is preempted not only takes away the power of state and local government to address an issue, it takes away the power of grassroots organizers to engage in democracy's most fundamental behavior: to debate whether and how law should address a social problem and to see organizing efforts made into law. Although much has been written about federal preemption of state and local law, almost no attention has been paid to the effect of preemption on political and civic engagement.

In the pages that follow, we begin by explaining the importance of local activism against the backdrop of the failure of federal law to constrain Wal-Mart's efforts to lower costs by paying inadequate wages and benefits and to thwart unionization by both legal and illegal tactics. Local activists pursue two common strategies to regulate Wal-Mart: fair-share health care legislation ${ }^{5}$ and zoning to exclude large low-wage retailers from a local market. ${ }^{6}$ Showing how preemption either derails local organizing (by invalidating fair-share laws) or deforms it (by forcing fights over working conditions into the alien territory of land-use law), we argue against excessively broad interpretation of the preemptive scope of federal law, particularly the Employee Retirement Income Security Act of 1974 (ERISA). ${ }^{7}$ For reasons we will explain, ERISA does not preempt local democratic initiatives, such as those recently attempted in Maryland. ${ }^{8}$ These initiatives force companies that do not provide adequate wages or health benefits to pay a tax to offset the cost to taxpayers of providing health care and basic social wel-

4. See U.S. CONST. art. VI, cl. 2 ("This Constitution, and the Laws of the United States which shall be made in Pursuance thereof . . . shall be the supreme Law of the Land ... ."); McCulloch v. Maryland, 17 U.S. (4 Wheat.) 316, 327 (1819) ("The laws of the United States, then, made in pursuance of the constitution, are to be the supreme law of the land ....").

5. See Edward A. Zelinsky, Maryland's "Wal-Mart" Act: Policy and Preemption, 28 CARDOZO L. REV. 847, 848-50 (2006) (discussing Maryland's "Fair Share" law that attempts to force for-profit employers with more than 10,000 employees to help pay for employee health care).

6. See Garrison \& Lin, supra note 1 (explaining the efforts of some California city governments to enact zoning rules designed to keep Wal-Mart out).

7. Pub. L. No. 93-406, 88 Stat. 829 (1974) (codified in scattered sections of 29 U.S.C.).

8. MD. CodE ANN., LAB. \& EMPL. §§ 8.5-101 to -107 (LexisNexis 1999 \& Supp. 2007), invalidated by Retail Indus. Leaders Ass'n v. Fielder, 475 F.3d 180 (4th Cir. 2007). 
fare protections to the working poor. We show that the recent split decision of the United States Court of Appeals for the Fourth Circuit, in Retail Industry Leaders Ass'n v. Fielder, which found ERISA to preempt the Maryland Fair Share Health Act, was based on an erroneous reading of the Supreme Court's leading ERISA cases. ${ }^{9}$ Moving beyond the technical arguments about the scope of ERISA preemption, we arguebased on an extensive literature on theories of organizing and civic democracy - that courts should narrowly construe the scope of federal preemption in the field of low-wage work and affordable health care. We thus bring to the law of preemption a new focus on the extraordinary importance in a democracy of local activism, organizing, and debate over social welfare. In sum, we contend that activists are right to persist in fighting for local democratic initiatives like the Maryland Fair Share Law even in the face of broad federal preemption, and lawyers for progressive local movements can properly find a space within ERISA preemption doctrine to defend the validity of these local initiatives.

\section{THE INADEQUACY OF FEDERAL REGULATION OF WAL-MART AND THE PROBLEM OF PREEMPTION OF STATE AND LOCAL LAW}

Wal-Mart has become the poster child for all that is wrong with an economy that generates a huge array of cheap consumer goods while sacrificing decent wages and adequate social welfare protections such as health care and retirement savings. Although a wide range of federal laws regulate working conditions, none has proved adequate to the task of constraining Wal-Mart's push to pay its employees as little as possible and to work them as hard as possible.

To begin, U.S. labor law has been incapable of checking the company's virulent antiunionism. ${ }^{10}$ In the absence of unions or effective enforcement of protective labor legislation, reports of

9. 475 F.3d at 197.

10. Wade Rathke, A Wal-Mart Workers Association? An Organizing Plan, in WAL-MART: THE FACE OF TWENTY-FIRST-CENTURY CAPITALISM 261, 268-69 (Nelson Lichtenstein ed., 2006). Not a single Wal-Mart store or department has unionized, or at least has done so without the company firing workers and closing the department (as in the case of the one group of Texas Wal-Mart employees who unionized and promptly lost their jobs), or the entire store (as in the case of Canadian Wal-Marts that were successfully organized and then promptly closed). Id. 
wage and hour violations abound, 11 as do assertions of exploitation of undocumented workers. ${ }^{12}$ Moreover, Wal-Mart is the defendant in the largest class action lawsuit ever brought under Title VII; allegations of endemic and widespread sex discrimination in pay and promotions were found sufficient to warrant certification of a class. ${ }^{13}$ In addition, the explosive growth of Wal-Mart's low-cost retailing model has had a devastating impact on small downtown commerce. The model has dramatically changed the nature of shopping, the prospects of small retail businesses, and the competitive position of unionized or higherwage retailers. ${ }^{14} \mathrm{In}$ all, the phenomenal growth of Wal-Mart's business model is a threat to an alternative retail business model in which consumer goods may cost more, but workers are also paid better and have more control over their working conditions.

The problem is not merely underenforcement of existing laws. Some of Wal-Mart's aggressive labor-cost controlling measures are legal under federal and state law. Recently, the retail giant has drastically restructured its labor practices by capping wages, using more part-time workers, scheduling work on nights and weekends, and demanding that workers be available around the clock every day of the year. Wal-Mart,

11. See, e.g., Abigail Goldman \& Nancy Cleeland, An Empire Built on Bargains Remakes the Working World, L.A. TIMES, Nov. 23, 2003, at A1 (describing how Wal-Mart's actions influence wages and working conditions world-wide); Steven Greenhouse, Wal-Mart Settles U.S. Suit About Overtime, N.Y. TIMES, Jan. 26, 2007, at C7 (reporting Wal-Mart's agreement to pay $\$ 33.5$ million to settle a U.S. Department of Labor lawsuit); Steven Greenhouse, Wal-Mart Told to Pay $\$ 78$ Million, N.Y. TIMES, Oct. 14, 2006, at C4 (reporting a $\$ 78$ million jury verdict in a class action case challenging a policy of requiring workers to work through rest breaks); Stacey Stowe, Connecticut Finds More Labor Law Violations at Wal-Mart, N.Y. TIMES, June 18, 2005, at B2 (noting that Connecticut investigators fined Wal-Mart for violating child labor laws at three stores).

12. Steven Greenhouse, Wal-Mart Suit Dismissed, N.Y. TIMES, Aug. 30, 2006, at A17 (describing a suit alleging Wal-Mart had conspired with cleaning contractors to abuse immigrant janitors).

13. Dukes v. Wal-Mart, 474 F.3d 1214, 1222-23 (9th Cir. 2007). The story behind the Dukes case is told in LIZA FEATHERSTONE, SELLING WOMEN SHORT: THE LANDMARK BATTLE FOR WORKERS' RIGHTS AT WAL-MART (2004), and in Brad Seligman, Patriarchy at the Checkout Counter: The Dukes v. Wal-Mart Stores, Inc. Class-Action Suit, in WAL-MART: THE FACE OF TWENTY-FIRSTCENTURY CAPITALISM, supra note 10, at 231, 231-42.

14. See generally Katharine B. Silbaugh, Wal-Mart's Other Woman Problem: Sprawl and Work-Family Balance, 39 CONN. L. REV. 1713, 1713-14 (2007) (explaining the effect of Wal-Mart's low-cost model on small-town retailers that charge slightly higher prices in exchange for added convenience). 
however, pays its workers only for hours actually worked. ${ }^{15}$ An internal corporate memo from the company's executive vice president in charge of human resources suggested that managers encourage long-time employees to quit because "the cost of an associate with 7 years of tenure is almost 55 percent more than the cost of an associate with 1 year of tenure, yet there is no difference in his or her productivity." 16

Nor does federal law provide a barrier to Wal-Mart offering low wages and paltry health benefits, even when it leads large numbers of its workers to rely on various forms of publicly funded social welfare programs. ${ }^{17}$ A 2005 internal memo to the Wal-Mart Board of Directors, prepared by Wal-Mart's senior executive in charge of human resources, showed that almost half of Wal-Mart employees' children were either uninsured or receiving Medicaid. Further, nearly forty percent of Wal-Mart employees spent an average of sixteen percent or more of their pay on health care, which is about four times the national average. ${ }^{18}$ The memo suggested that the company's health care costs could be contained by restructuring jobs to require more physical activity. This recharacterization would dissuade unhealthy people from working for Wal-Mart and would encourage the use of more part-time workers who would not be eligible for or could not afford the health insurance plan that the company provides. ${ }^{19}$ These policies and practices are largely beyond the effective power of federal law.

15. Steven Greenhouse \& Michael Barbaro, Wal-Mart to Add More PartTimers and Wage Caps, N.Y. TIMES, Oct. 2, 2006, at A1.

16. Id.

17. See generally ARINDRAJIT DUBE \& KEN JACOBS, HidDEN COST OF WAL-MART JOBS: USE OF SAFETY NET PROGRAMS BY WAL-MART WORKERS IN CALIFORNIA 1 (U.C. Berkeley Center for Labor Research and Education, Aug. 2, 2004), available at http://laborcenter.berkeley.edu/retail/walmart.pdf (finding that families of Wal-Mart employees use approximately forty percent more in taxpayer-funded health care than the average for families of all large retail employees and thirty-eight percent more in other non-health-care public assistance programs, such as food stamps, Earned Income Tax Credit, subsidized school lunches, and subsidized housing); Joshua Green, The New War Over Wal-Mart, ATLANTIC MonTHLY, June 2006, at 38, 41-42.

18. Reed Abelson, Everyday High Health Costs, N.Y. TIMES, Oct. 29, 2005, at $\mathrm{C} 1$.

19. Id.; see also Pallavi Gogoi \& Robert Berner, Wal-Mart Puts on a Happy Face, BUS. WK. ONLINE, Apr. 19, 2006, http://www.businessweek.com/investor/ content/apr2006/pi20060419_152855.htm (describing new company health benefit plans with expanded coverage for part-time employees but noting that many plans would be unaffordable for Wal-Mart employees). 
Moreover, the strategies that would enable worker advocates to challenge Wal-Mart's labor practices most directly are largely foreclosed by inadequate federal protection of the right to unionize. ${ }^{20}$ Workers could combat Wal-Mart's low wages and inadequate benefits head-on by unionizing and bargaining for better conditions. Federal labor law, unfortunately, gives employers a wide array of tools to fight workplace organizing. Employers enjoy federally protected rights to refuse to recognize a union that enjoys the majority support of its workers, to run a lengthy and intimidating antiunion campaign, to illegally fire union supporters without facing meaningful penalties, to permanently replace striking workers, and to close down any operation that unionizes. ${ }^{21}$ It is well known that Wal-Mart has made the most of the power it enjoys under federal law-the company employs an entire staff of antiunion experts whom it dispatches to quell any sign of unionization. ${ }^{22}$

The patent shortcomings of federal labor law are accompanied by the lack of any federal mandate requiring employers to offer health or pension benefits to its employees. ERISA, the federal law that regulates pensions and health benefits, does not require employers to provide benefits; it merely imposes some limits on the design and administration of the benefits plans the employer voluntarily provides. ${ }^{23}$ Thus, federal law provides no assistance to workers at Wal-Mart and other low-

20. Federal preemption compounds the problem by preventing localities and states from enacting laws intended to facilitate unionization. See Michael H. Gottesman, Rethinking Labor Preemption: State Laws Facilitating Unionization, 7 YALE J. ON REG. 355, 364-66, 394-96 (1990) (discussing the shortcomings of the National Labor Relations Act and arguing that the preemption doctrine should not prevent states from passing labor laws outside the "continuum" of federal regulations).

21. Id. at 362-74.

22. Rathke, supra note 10, at 269-70. In a discussion of Wal-Mart's unionbusting tactics, Rathke writes that

[t]oday, Wal-Mart maintains a staff of [200] in its labor relations department, many available to fly to any store when the UPI-Union Prevention Index-hits a prescribed set of bells. . . . Of course, when a real unionization effort is detected, Bentonville springs into action with all necessary resources. For example, in February 2005, when eighteen tire-and-lube-shop workers in a Loveland, Colorado, WalMart prepared for an NLRB election, headquarters flew in a team of labor relations experts who hammered away at the luckless young workers for more than a week. . . Not unexpectedly, the union lost, $17-1$.

Id.

23. 29 U.S.C. $§ 1003$ (2000 \& Supp. V 2002). 
wage companies who wish to challenge their working conditions.

Despite this inadequate federal regulatory framework, Wal-Mart nevertheless still confronts a serious challenge to its policies: local activism. ${ }^{24}$ Websites, books, films, and formal coalitions have emerged to aid and foment community-level antiWal-Mart efforts. ${ }^{25}$ Such activism is not necessarily special; to varying degrees, organizing that is responsive to a variety of local issues, not just an encroaching Wal-Mart, persists throughout the American landscape. ${ }^{26}$ But Wal-Mart's place in the context of local organizing may be unique. As the "template business" 27 for the twenty-first century American economy, ${ }^{28}$ the company symbolizes a triumph of consumerist values, ${ }^{29}$ where "everyday low prices" 30 are said to create wealth and

24. See Andy Serwer, Bruised in Bentonville, ForTune, Apr. 18, 2005, at 84, 84 ("From Chicago to New Orleans to California to New York (never mind Quebec and Mexico), news that Wal-Mart is coming to town is now often greeted with protests.").

25. See, e.g., David Porter \& Chester L. Mirsky, Megamall on the HUDSON: PLANNING, WAL-MART, AND GRASSROOTS RESISTANCE (2003) (providing a first-person, meticulously detailed account of an anti-Wal-Mart campaign to help other local activists in similar efforts); Brave New Films, WalMart: The High Cost of Low Prices, http://www.walmartmovie.com/about.php (last visited Apr. 18, 2008) (describing a film that documents communities struggling against Wal-Mart); Wake-Up Wal-Mart: Community Fights, http:// wakeupwalmart.com/community (last visited Apr. 18, 2008) (listing "5 Steps to Keep Your Community 'Wal-Mart Free”').

26. See generally Michael GECAN, GoIng PUBLIC (Anchor 2004) (2002) (describing various and successful community change initiatives); ROBERT D. PutNAM \& LEWIS M. FELDSTEIN, BeTTER TOGETHER (2003) (depicting and analyzing a variety of communities and institutions around the country where civic activism thrives).

27. Nelson Lichtenstein, Wal-Mart: A Template for Twenty-First-Century Capitalism, in WAL-MART: THE FACE OF TWENTY-FIRST-CENTURY CAPITALISM, supra note 10, at 3, 4 .

28. See Editorial, The Wal-Martization of America, N.Y. TIMES, Nov. 15, 2003, at A12 ("This Wal-Martization of the work force, to which other low-cost, low-pay stores also contribute, threatens to push many Americans into poverty.").

29. See Schragger, supra note 1, at 1087-91 (calling Wal-Mart the symbol of a modern economy focused on providing low-cost consumer goods regardless of the effect on local communities).

30. Anthony Bianco \& Wendy Zellner, Is Wal-Mart Too Powerful?, Bus. WK., Oct. 6, 2003, at 100 ("At Wal-Mart, 'everyday low prices' is more than a slogan; it is the fundamental tenet of a cult masquerading as a company."); see also SAM Walton WITH JOHn Huey, SAM WALTON: MADE IN AMERICA 50 (1992) ("What we were obsessed with was keeping our prices below everybody else's. Our dedication to that idea was total."). 
unmatched societal benefits, ${ }^{31}$ over producerist values, ${ }^{32}$ where workers create wealth and should have the power to possess it. 33 The difference, laments political philosopher Michael Sandel, is morality: "Instead of asking how to elevate or improve or restrain people's preferences, [consumerism] asks how bestmost fully, or fairly, or efficiently-to satisfy them." 34 The antiWal-Mart movement, however, pushes back. Its rhetoric is steeped in producerist critiques of the company's low wages and inadequate benefits. ${ }^{35}$ Wal-Mart's prominence in the American

\section{As a Fortune article argued in 2003:}

By systematically wresting "pricing power" from the manufacturer and handing it to the consumer, Wal-Mart has begun to generate an economy-wide Wal-Mart Effect. Economists now credit the company's Everyday Low Prices with contributing to Everyday Low Inflation .... A 2002 McKinsey study, moreover, found that more than oneeighth of U.S. productivity growth between 1995 and 1999 could be explained "by only two syllables: Wal-Mart."

Jerry Useem, One Nation Under Wal-Mart: How Retailing's Superpower-and Our Biggest Most Admired Company-Is Changing the Rules for Corporate America, ForTune, Mar. 3, 2003, at 64, 68 (discussing economic studies that show Wal-Mart has contributed substantially to low inflation and increased productivity). In the article, Warren Buffett states that Wal-Mart has "contributed to the financial well-being of the American public more than any institution I can think of." Id. See generally JASON FURMAN, WAL-MART: A PROGRESSIVE SUCCESS STORY 15 (Nov. 28, 2005), http://www.americanprogress .org/kf/walmart_progressive.pdf (citing economic data to argue that Wal-Mart is a "progressive success story" that has resulted in "huge benefits" for middleand low-income Americans and that the company's critics are misguided).

32. KAZIN, supra note 2, at 56, 162-63 (describing the producerist ethic as "labor creates all wealth" and that "power should be wielded at least as much by those who create wealth as by those who possess it").

33. Id.; see also Schragger, supra note 1, at 1086-87 (noting the shift between consumerist and producerist ethics and questioning "[w]hether the nation has made the correct tradeoff between consumer sovereignty and individual . . . self-sufficiency"). In contrast, through the consumerist lens workers gain wealth only tangentially, in the form of lower prices. See Steven Greenhouse, Opponents of Wal-Mart to Coordinate Efforts, N.Y. TIMES, Apr. 3, 2005, at A20 ("[Wal-Mart CEO Lee] Scott cited studies estimating that Wal-Mart saves American consumers $\$ 100$ billion a year and saves the average family $\$ 600$ a year, '[giving] them a raise every time they shop with us."').

34. MICHAEL J. SANDEL, DEMOCRACY'S DISCONTENT 225 (1996).

35. See, e.g., Greenhouse, supra note 33 ("[An anti-Wal-Mart coalition] plan[s] to put forward an association of disenchanted Wal-Mart employees, current and former, to complain about what they call poverty-level wages and stingy benefits."); Steven Greenhouse, Unions to Push for Better Pay at WalMart, N.Y. TIMES, Dec. 11, 2004, at A16 [hereinafter Greenhouse, Unions] (describing a massive campaign "intended to pressure Wal-Mart, the world's largest retailer, to improve its wages and benefits"); Wake Up Wal-Mart: Why Wal-Mart Must Change, http://www.wakeupwalmart.com/change (last visited Apr. 18, 2008) (contrasting Wal-Mart's low-wage, low-benefit vision for America with the movement's living-wage, adequate-benefits vision for America). 
consciousness, ${ }^{36}$ the sheer number of ongoing Wal-Mart battles (with the associated media attention), ${ }^{37}$ and the wide variety of actors involved in any single fight 38 inspire optimism that a producerist ethic-and its attendant moral economic lenscould return.

Unfortunately, where local activists gather the energy and strength required to rectify the failures of federal regulation, their efforts can be thwarted by federal preemption of state and local laws. Courts have increasingly found that even inadequate federal laws preempt state and local laws that may offer greater protection to workers. They have concluded that the National Labor Relations Act (NLRA) broadly preempts state laws regulating union organizing and collective bargaining. ${ }^{39}$ Similarly, ERISA preempts state laws that "relate to any employee benefit plan" covered by ERISA, which means that it preempts state and local laws that require employers to provide health, retirement, or any other benefit that is administered through a "plan." 40 Because most private-sector employers (in-

36. See Michael Barbaro, Is Wal-Mart Too Cheap for Its Own Good?, N.Y. TIMES, May 30, 2007, at C1 (noting that "Wal-Mart attracts 138 million shoppers a week, a staggering figure unmatched in American retailing" and that sixty-seven percent of Americans say the company is their number one destination for discount shopping).

37. See, e.g., Greenhouse, supra note 33; Greenhouse, Unions, supra note 35. The Website walmartwatch.com cites more than thirty formal organizations actively seeking to prevent Wal-Mart from entering their communities.

Wal-Mart Watch: Battle-Mart Site Fights, http://walmartwatch.com/ battlemart/pages/site_fights (last visited Apr. 18, 2008).

38. Efforts to prevent Wal-Mart from locating in Inglewood, California, for instance, involved elected officials, members from two unions, Inglewood citizens, and a wide variety of previously existing faith and secular groups "coalesced around the clear threat of the Wal-Mart initiative" to form the Coalition for a Better Inglewood. Scott L. Cummings, Law in the Labor Movement's Challenge to Wal-Mart: A Case Study of the Inglewood Site Fight, 95 CAL. L. REV. 1927, 1960 (2007).

39. See, e.g., Gottesman, supra note 20, at 355 (observing that "prevailing wisdom" states that the NLRA "wholly preempts the states' ability to adopt laws facilitating unionization").

40. 29 U.S.C. $\$ 1144$ (a) (2000). A plan covered by ERISA is a "plan, fund or program ... established or maintained by an employer or by an employee organization, or by both, to the extent that" the plan provides various benefits specified in the statute. 29 U.S.C. § 1002(1) (2000). For example, prior to the enactment of ERISA, Hawaii enacted legislation requiring certain employers to provide health benefits to employees. HAW. REV. STAT. $\S \S 393-1$ to -51 (1993). Litigation was filed shortly after ERISA became effective and the Hawaii scheme was declared preempted. Standard Oil v. Agsalud, 633 F.2d 760 (9th Cir. 1980), aff'd, 454 U.S. 801 (1981). But ERISA was later amended-at the behest of Hawaiian senators - to save the program. 29 U.S.C. $§ 1144(b)(5)$. 
cluding Wal-Mart) provide health care benefits through a plan covered by ERISA, preemption thus invalidates state or local laws that mandate that employers provide health insurance.

In all, ERISA preemption forecloses direct attacks on WalMart's low wages and paltry health benefits, and labor preemption makes it impossible for workers to enact state laws that make it feasible to organize themselves collectively and demand better wages. The ability of communities to insist on a fundamentally different vision of the relationship between labor and consumers - a producerist ethic or a higher wage, higher price strategy-is thwarted by preemption.

\section{STATE AND LOCAL ORGANIZING AGAINST LOW- WAGE RETAIL WORK: FAIR-SHARE LAWS AND FIGHTS OVER LAND-USE PLANNING}

With avenues to improve low-wage jobs and benefits through unionization or mandated employee benefits foreclosed by preemption, local activists have turned to areas of law that appear to be immune from preemption. In some jurisdictions, activists have pressed for the enactment of legislation that would require large employers either to spend a certain percentage of their annual payroll expenditures on employee health care or to pay a tax to offset the government's costs of providing health care for the uninsured. Although there is a good argument that this "fair-share" legislation is not a benefits mandate and therefore not preempted by ERISA, the recent Fourth Circuit decision in Retail Industry Leaders Ass'n v. Fielder casts some doubt on the viability of such legislation. ${ }^{41}$ The alternative strategy, which is largely immune from federal preemption challenges, is to use local governments' land-use planning powers to ban Wal-Mart from certain areas. As we will explain, if ERISA preemption challenges push activists away from efforts to regulate wages and health insurance and into waging landuse site fights against low-wage employers, then the costs of preemption for local governance and civic democracy are higher than is recognized.

For an argument explaining why ERISA does not preempt every state law that mandates payments to employees, see Catherine L. Fisk, ERISA Preemption of State and Local Laws on Domestic Partnership and Sexual Orientation Discrimination in Employment, 8 UCLA WOMEN's L.J. 267, 291-94 (1998).

41. 475 F.3d 180 (4th Cir. 2007). 


\section{A. FAIR-SHARE LAWS AND ERISA PREEMPTION}

"Fair-share" or "pay or play" laws require an employer that does not provide health benefits to pay a tax or fee to cover the cost to the government of providing health care to low-wage workers. ${ }^{42}$ Around the country, fair-share and living-wage laws are supported by coalitions of unions representing workers in low-wage industries, ${ }^{43}$ grass-roots antipoverty organizations like Association of Community Organizations for Reform Now (ACORN), health care reform groups, and often faith-based groups with concerns about poverty. Their legislative goals are usually two-fold: to increase cash wages and access to health insurance. Fair-share legislation has been enacted in Massachusetts, Maryland, San Francisco, and Suffolk County, New York, and is being considered in other places, including California. ${ }^{44}$

Maryland's Fair Share Act requires every employer of 10,000 or more Maryland employees to pay to the state an amount equal to the difference between what the employer spends on "health insurance costs" (a wide range of healthrelated expenses including health insurance premiums, contributions to health savings accounts, and the direct provision of health care to employees) and eight percent of its payroll costs. ${ }^{45}$ An employer that paid eight percent of its payroll in health expenses would pay nothing to the government. An employer that paid no health expenses would pay an eight percent payroll tax, and other employers would pay something in between. ${ }^{46}$ Maryland has few employers with more than 10,000 employees, and none except Wal-Mart pays less than eight percent of payroll in health expenses. Thus, as a practical matter

42. Amy Worden, Many Wal-Mart Workers Use Medicaid, PHILA. INQUIRER, Mar. 2, 2006, at A1.

43. E.g., UFCW Facts: The Truth about Wal-Mart, http://www.grocery workersunited.org/walmarts_impact.html (last visited Apr. 18, 2008) (voicing support for fair-share laws and urging the rest of the membership of the United Food and Commercial Workers International Union (UFCW) to support efforts to enact fair-share legislation).

44. See, e.g., Amy B. Monahan, Pay or Play Laws, ERISA Preemption, and Potential Lessons from Massachusetts, 55 KAN. L. REV. 1203, 1204 (2007). The Maryland and Suffolk County legislation are described in detail below. The Massachusetts legislation was repealed. MASS. GEN. LAWS ch. 149, § 188 (2006), amended by 2007 Mass. Legis. Serv. 61 (West).

45. $2006 \mathrm{Md}$. Laws 1; MD. CODE ANN., LAB. \& EMPL. $\S \S 8.5-101$ to -107 (LexisNexis 1999), invalidated by Retail Indus. Leaders Ass'n v. Fielder, 475 F.3d 180 (4th Cir. 2007).

46. MD. CODE ANN., LAB. \& EMPL. §§ 8.5-104(b). 
the statute would change only Wal-Mart's payroll costs. Suffolk County's Fair Share for Health Care Act operates similarly. The Act required covered employers to make minimum employee health care expenditures equivalent to a portion of the cost to the public health care system of providing care to an uninsured employee. ${ }^{47}$ The intent of the Massachusetts, Maryland, and Suffolk County legislation was to protect employers that provide health benefits and the public fisc from "unfair" competition from large employers that fail to provide health benefits. ${ }^{48}$ There are two reasons laws are drafted with the option of paying a more generous benefits package or paying an equivalent sum to some other person or entity. One is to avoid penalizing those employers that already provide generous benefits, and the other is to avoid ERISA preemption.

A living-wage law tries to achieve a similar goal through simple wage regulation: the employer must pay a wage of a certain amount plus benefits, or it can pay a higher cash wage but no benefits. This approach is used in most living-wage ordinances and was recently tried in Chicago in a 2006 ordinance (which failed to survive a mayoral veto) that targeted big-box retailers. ${ }^{49}$ Unlike fair-share laws, living-wage laws are not vulnerable to federal preemption because the Fair Labor Standards Act, which regulates minimum wages, explicitly states that it does not preempt "any Federal or State law or municipal ordinance establishing a minimum wage higher than the minimum wage established under this chapter." 50 On the other hand, lower courts have concluded that ERISA does not preempt wage regulation schemes that calculate the minimum wage by reference to whether benefits are paid because they

47. Suffolk County, N.Y., ReG. Local LaWs § 325-3 (2005); see also N.Y.C. ADMIN. CODE § 22-506(c)(2) (2004).

48. Fielder, 475 F.3d at 183-84; Retail Indus. Leaders Ass'n v. Suffolk County, 497 F. Supp. 2d 403, 408 (E.D.N.Y. 2007).

49. See, e.g., Gary Washburn \& Mickey Ciokajlo, 'Big-Box' Wage Law Passes, Aldermen Defy Mayor, Anger Retailers, CHI. TRIB., July 27, 2006, at 1 (describing the Illinois Retail Merchants Association's plans to challenge the constitutionality of the ordinance). Even before the measure was vetoed, there were doubts about whether it would survive a preemption challenge. See Michael Higgins \& Gary Washburn, 'Big-Box' Law Faces Test, City Lawyers Advised Before Vote That Measure Legally Suspect, CHI. TRIB., July 28, 2006, at 1 (suggesting Chicago's big-box ordinance, like others around the country, faced difficult legal challenges). The ordinance was finally defeated by a mayoral veto. See Gary Washburn \& Mickey Ciokajlo, Daley Vetoes 'Big-Box Law,' CHI. TRIB., Sept. 12, 2006, at 11, 13.

50. 29 U.S.C. $\$ 218(2000)$. 
deem such statutes permissible wage regulation rather than preempted benefits mandates. ${ }^{51}$ Under a doctrine known as home rule, many municipalities are authorized by their state constitutions to enact legislation relating to wages and working conditions to safeguard the health, safety, and welfare of the community. ${ }^{52}$ Although living-wage laws have proved relatively safe from preemption, health care advocates believe that they do not address the problem of the uninsured because the cost of health insurance for individuals is prohibitive and only groupbased health insurance (such as employer provided insurance) spreads the risk among a large enough pool of people to make the insurance affordable. Thus, fair-share legislation remains the preferred approach to addressing the lack of health care for the working poor.

Some courts have concluded that ERISA preempts fairshare laws. Most recently, the majority in a split Fourth Circuit decision concluded that ERISA preempted the Maryland Fair Share Health Act. ${ }^{53}$ The majority reasoned that the Act's employer spending and benefit requirements fell within ERISA's preemption provision because it effectively compelled employers to adjust their expenditures under their ERISA plans. ${ }^{54}$

Maryland defended its law on the ground that the plan did not compel employers to establish or alter an ERISA plan; employers were free to pay the tax to the government or to make health care payments directly to the employees through general funds. ${ }^{55}$ The tax was not high enough to be a covert effort to force employers to provide benefits. Wal-Mart conceded that if it chose the tax option it faced an assessment of only one per-

51. See e.g., Burgio v. N.Y. Dep't of Labor, 107 F.3d 1000, 1011 (2d Cir. 1997); WSB Elec. v. Curry, 88 F.3d 788, 796 (9th Cir. 1996); Minn. Chapter of Assoc. Builders \& Contractors, Inc. v. Minn. Dep’t of Labor, 47 F.3d 975, 981 (8th Cir. 1995); Keystone Chapter, Assoc. Builders \& Contractors, Inc. v. Foley, 37 F.3d 945, 963 (3d Cir. 1994).

52. See, e.g., CAL. LAB. CODE $\S 1205(b)$ (West 2003) (stating that California state law does not preempt power of cities to exercise police powers); Baltimore v. Sitnick, 255 A.2d 376, 396 (Md. 1969) (finding that Maryland cities have power to enact wage laws); New Mexicans for Free Enter. v. City of Santa Fe, 126 P.3d 1149, 1160 (N.M. Ct. App. 2005) (concluding that a living-wage ordinance is within city's home rule powers and not preempted by state law); Darin M. Dalmat, Note, Bringing Economic Justice Closer to Home: The Legal Viability of Local Minimum Wage Laws Under Home Rule, 39 CoLUM. J.L. \& Soc. PROBS. 93, 112-26 (2005).

53. Retail Indus. Leaders v. Fielder, 475 F.3d 180, 198 (4th Cir. 2007).

54. Id. at $193-94,197$.

55. Id. at 194-96. 
cent of its Maryland payroll expenditures. ${ }^{56}$ Nevertheless, the Fourth Circuit majority decided the statute was effectively a mandate. 57 The tax provided an incentive for employers to establish or to improve their ERISA-covered health benefit plans, and the court therefore reasoned that a "reasonable employer" would not forego the chance to improve the morale of present employees and the ability to attract more and better new employees by offering benefits. ${ }^{58}$ In contrast, "an employer would gain nothing in consideration of paying a greater sum of money to the state" because "it might suffer from lower employee morale and increased public condemnation."59

The majority did not distinguish, nor did it even cite, any of the cases upholding living-wage laws that gave employers the option of paying more cash or less cash plus health or other benefits. These laws, like the Maryland law, create an incentive for employers to gain the goodwill of their employees and the public by providing benefits. As the dissent pointed out, the lower court decisions upholding living-wage laws emphasize that such laws impose only a slight burden of calculating and reporting amounts spent on health care benefits, and this burden is too slight to trigger ERISA preemption. ${ }^{60}$

Maryland also defended its law on the ground that employers could make health care expenditures on behalf of employees by funding clinics or through other sorts of expenditures that did not require the establishment of an ERISA plan. ${ }^{61}$ This argument found support in two Supreme Court decisions, Fort Halifax Packing Co. v. Coyne, ${ }^{62}$ and Massachusetts v. Morash, ${ }^{63}$ which held that ERISA does not preempt state laws requiring the payment of severance pay and unused vacation pay to employees because these laws affected "payroll practices," not benefit plans. ${ }^{64}$ The Supreme Court reasoned that although

56. Id. at 202 (Michael, J., dissenting).

57. Id. at 198 (majority opinion).

58. Id. at 193 .

59. $I d$.

60. Id. at 201-02 (Michael, J., dissenting) (citing Burgio \& Campofelice, Inc. v. N.Y. State Dep't of Labor, 107 F.3d 1000, 1009 (2d Cir. 1997); Keystone Chapter, Assoc. Builders \& Contractors, Inc. v. Foley, 37 F.3d 945, 961 (3d Cir. 1994); Minn. Chapter of Assoc. Builders \& Contractors, Inc. v. Minn. Dep't of Labor \& Indus., 866 F. Supp. 1244, 1247 (D. Minn. 1993)).

61. Fielder, 475 F.3d at 196.

62. 482 U.S. 1,19 (1987).

63. 490 U.S. $107,112-14$ (1990).

64. Id. at 108 . 
these benefits might be offered in programs that constitute ERISA plans, they need not be because such benefits are usually paid out of general operating revenues and do not require substantial reserves to be calculated based on complex actuarial assumptions. ${ }^{65}$ The Fourth Circuit rejected the analogy between these state laws and the Maryland fair-share law because it would be administratively difficult to make the required health care expenditures unless they established an ERISA plan. ${ }^{66}$

The Fourth Circuit majority's analysis is inconsistent with a number of the Supreme Court's most recent ERISA preemption decisions. In New York State Conference of Blue Cross \& Blue Shield Plans v. Travelers Ins. Co., the Court upheld a New York law that regulated the cost of hospital services and provided a lower cost if services were paid by nonprofit providers than if the costs were paid by for-profit insurers. ${ }^{67}$ Although Travelers Insurance Company argued that ERISA preempted the law because it regulated employee benefit plans, the Court disagreed, explaining that the health reimbursement law did not "bind plan administrators to any particular choice" 68 about which benefits to provide, nor did it "preclude uniform administrative practice or the provision of a uniform interstate benefit package if a plan wishes to provide one." 69 The Court concluded that state laws could impose different costs on ERISA plans without triggering ERISA preemption because "cost uniformity [between states] with only an indirect economic effect on the relative costs of various health insurance packages in a given State are a far cry from those conflicting directives from which Congress meant to insulate ERISA plans."70

Similarly, in California Division of Labor Standards Enforcement $v$. Dillingham Construction Co., the Court rejected an ERISA preemption challenge to a state law that required employers to pay prevailing-wage rates to apprentices. ${ }^{71}$ Because most apprenticeship programs, including the ones at issue in Dillingham, were ERISA plans, the law effectively required

65. Coyne, 482 U.S. at 11-12.

66. Fielder, 475 F.3d at 196-97.

67. 514 U.S. 645,645 (1995).

68. Id. at 659 .

69. Id. at 660 (citing Ingersoll-Rand Co. v. Melendan, 498 U.S. 133, 142 (1990)).

70. Id. at 662 (citing Ingersoll-Rand Co., 498 U.S. at 139).

71. 519 U.S. 316, 316 (1997). 
employers to participate in an ERISA plan. Nevertheless, because it was possible for a state-approved apprenticeship program to be financed from the employer's general assets rather than through an ERISA plan, the Court decided that the state law functioned "irrespective of ... the existence of an ERISA plan" and was therefore not preempted. ${ }^{72}$

Read together, these cases suggest that ERISA preempts laws if they can be complied with only by adopting an ERISAcovered benefit plan or by changing the terms of an ERISA plan. Conversely, laws that regulate working conditions but will affect employees hired or paid through an ERISA plan (as in Dillingham) or that regulate the cost of health care and affect the amount that ERISA plans pay for certain kinds of health care services (as in Travelers) are not preempted. ERISA does not preempt these laws because they primarily regulate something within the legitimate sphere of state and local government and affect ERISA plans in pursuit of the local regulatory objective. As noted above, laws that primarily regulate payroll practices but could affect employers who provide certain compensation through a benefits plan are not preempted under the reasoning of Fort Halifax Packing Company v. Coyne ${ }^{73}$ and Massachusetts $v$. Morash ${ }^{74}$ which allow states to regulate leave policies and to mandate payment for unused sickness or vacation leave even though sometimes the sums are paid by an ERISA-covered plan. ${ }^{75}$ In other words, ERISA does not preempt state statutes that provide an indirect incentive for employers to make expenditures that could be covered through an ERISAcovered plan but that would not have to be. ${ }^{76}$

The Fourth Circuit majority's argument set these cases aside because, in its view, unlike the state laws at issue there, the Maryland Fair Share Health Act effectively compelled covered employers to make health care expenditures either into an ERISA plan directly or set by reference to the amount that would be paid to an ERISA plan if the employer had one. ${ }^{77}$ Principal support for this contention was based on the Supreme

72. Id. at 328 .

73. 482 U.S. 1, 7-8 (1987) (holding that ERISA preempts state laws relating to employee benefit plans rather than employee benefits in general).

74. 490 U.S. 107 (1989).

75. Id. at $113-21$.

76. See New York State Conference of Blue Cross \& Blue Shield Plans v. Travelers Ins. Co., 514 U.S. 645, 653 (1995).

77. Retail Indus. Leaders Ass'n v. Fielder, 475 F.3d 180, 193-94 (4th Cir. 2007). 
Court's decision in District of Columbia v. Greater Washington Board of Trade, ${ }^{78}$ which invalidated a provision of a D.C. workers' compensation law that required employers that provided medical insurance to employees to provide equivalent insurance to any employee who received or was eligible to receive workers' compensation. ${ }^{79}$ In that case, however, the local law was an absolute mandate to provide benefits, and there was no option to pay a tax or to make expenditures other than through an ERISA plan. ${ }^{80}$ In both Travelers and Dillingham, the Court emphasized that ERISA should not be interpreted to preempt laws within the traditional police powers of the states unless the law requires the employer to provide benefits or forbids a method of calculating benefits that federal law permits. ${ }^{81}$ Regulation of wages and dealing with the problem of health care for the poor are within the scope of traditional police powers. ${ }^{82}$ As noted above, fair-share laws do not require employers to provide benefits through an ERISA plan and do not forbid ERISA plans from operating in any particular way. ${ }^{83}$ While it is true that such laws provide an incentive for employers to establish an ERISA plan or to improve benefits under one, those laws do not require it. And that requirement is the crucial aspect of the ERISA preemption analysis.

Courts must make judgments in deciding ERISA preemption issues about the degree of effect a state law may have on an ERISA plan. ${ }^{84}$ That judgment is inevitable, and in the case of the Maryland Fair Share and other similar laws, the question is whether the effort to fund health care shades too much toward an effort to dictate the content of ERISA plans, or ra-

78. 506 U.S. 125,129 (1992).

79. Id.

80. See id. at 128 (describing the requirements of the law at issue).

81. See De Buono v. NYSA-ILA Med. \& Clinical Servs. Fund, 520 U.S. 806, 813 n.8 (1997); California Division of Labor Standards Enforcement v. Dillingham Construction Co., 519 U.S. 316, 325 (1997); Travelers, 514 U.S. at $654-55$.

82. See, e.g., Travelers, 514 U.S. at 668 (stating that regulation of insurance and matters relating to health are within police powers); De Canas v. Bica, 424 U.S. 351, 356 (1976) (holding that regulation of employment is within police powers).

83. See supra notes 41-61 and accompanying text.

84. Catherine L. Fisk, The Last Article About the Language of ERISA Preemption? A Case Study of the Failure of Textualism, 33 HARV. J. ON LEGIS. 35, 90-91 (1996) (arguing that in the analysis of whether a state law "relates to" an employee benefit plan, judges should focus on the policy underlying ERISA instead of statutory text, which is inherently ambiguous). 
ther is an effort to regulate wages and health care that has an effect on ERISA plans. To accept the Fourth Circuit majority's characterization of the Maryland statute as a benefit mandate, ${ }^{85}$ one must ignore all the cases that uphold livingwage laws against ERISA preemption challenges. If livingwage legislation allowing an employer to choose between paying more cash, or less cash plus benefits to employees, is not preempted because it does not sufficiently "relate to" an ERISA plan, courts should not deem legislation allowing an employer to choose between paying $\$ \mathrm{X}$ to the government or $\$ \mathrm{X}$ to employees in the form of health care to "relate to" an employee benefit plan.

Contrary to the Fourth Circuit majority's characterization, an employer who thought it economically unwise or administratively infeasible to pay health care costs might conclude that paying the tax was the rational option. The tax would compel employers to provide benefits only if the tax was dramatically more expensive than paying benefits, and in Maryland, it was not. As applied to Wal-Mart, the tax would be only one percent of payroll. Even an employer who made no health care expenditures would pay a maximum tax of eight percent of payroll. Since the Maryland law made the tax equivalent to the cost of providing benefits, it is hard to see how the law was really a mandate to provide benefits. As the Fourth Circuit majority recognized, the only reason an employer would choose to pay benefits rather than the tax is to make its employees happy. Therefore, on the court's reasoning, the real choice confronting the employer is the administrative cost of altering its health benefits policies as compared to the personnel costs of having disgruntled employees (while still paying up to eight percent of payroll in health care expenditures). The employer's own fear of employee wrath is hardly a government mandate.

The Fourth Circuit majority also reasoned that

the Fair Share Act and a proliferation of similar laws in other jurisdictions would force Wal-Mart or any employer like it to monitor these varying laws and manipulate its healthcare spending to comply with them, whether by increasing contributions to its ERISA plans or navigating the narrow regulatory channel between the Fair Share Act's definition of healthcare spending and ERISA's definition of an employee benefit plan. ${ }^{86}$

85. Retail Indus. Leaders Ass'n v. Fielder, 475 U.S. F.3d 180, 193-94 (4th Cir. 2007).

86. Id. at 197 . 
This suggests that ERISA preempts any state or local law that requires an employer to "monitor" local laws and change its pay practices accordingly, if the employer would have to tweak its spending to avoid paying out more in cash by paying more in health benefits. That reasoning is flatly inconsistent both with the Supreme Court's decisions and with lower court decisions upholding living-wage laws. ${ }^{87}$

Even if the Fourth Circuit majority's view were to become the law nationwide, employee activists are still right to persist in seeking the enactment of fair-share legislation because such laws can be written to comply with the court's strict limits. To take one example, a state could impose a payroll tax specifically denominated to raise revenue to fund Medicaid and give employers who provide health benefits a credit reflecting the amount or percentage of payroll it spends on health care. ${ }^{88}$ The tax would seem less like an effort to coerce employers to provide benefits if the employer that spent less on benefits than required by the tax could be eligible for the full credit by spending only half as much in health costs on its employees (because employer expenditures on benefits are deductible from the employer's income tax as a business expense). 89 Thus, if the Medicaid revenue tax were set at ten percent of payroll, an employer who presently paid no benefits could be exempt from the tax by paying five percent of payroll to employees in health costs. An employer that currently spent four percent of payroll on health costs could get a full credit against the other six percent by paying an additional three percent of payroll in health costs. This scheme would allow only states to enact fair-share laws, as municipalities do not fund Medicaid. If municipal legislation were enacted, presumably, it would have to be designed to raise revenue to fund whatever part of health costs are paid by municipalities.

In sum, fair-share legislation remains a viable, if complex, arena for local activism. While preemption litigation can be prolonged, complex, and pose a threat to the immediate success of local activism, there is a way to avoid ERISA preemption.

87. See supra notes 73-76 and accompanying text.

88. Darren Abernethy, Note, Of State Laboratories and Legislative Alloys: How "Fair-Share" Laws Can Be Written to Avoid ERISA Preemption and Influence Private Sector Health Care Reform in America, 49 WM. \& MARY L. REV. $1859,1883-84$ (2008).

89. Id. at $1884-85$. 


\section{B. LAND-Use Planning as A StRategy to AdDREss Low-WAGE WORK}

With federal labor and ERISA preemption foreclosing some avenues for attacking low-wage labor conditions directly and raising the specter of expensive and prolonged federal court litigation, activists often turn to zoning or land-use laws to control Wal-Mart's entry into a local, regional, ${ }^{90}$ or state market. ${ }^{91}$ These "site fights" use local planning regulation to prevent or restructure development proposals by imposing parking, aesthetic, or site-layout standards, building size or display and sale limits, or environmental and community impact assessment requirements. ${ }^{92}$ Some localities wield their zoning powers to summarily ban superstores like Wal-Mart,93 while others scrutinize proposals on a case-by-case basis, approving projects only if conditions are agreed to or met. ${ }^{94}$ Nearly every site fight involves diverse coalitional support, often including labor unions, faith-based organizations, and community groups.95 And since land use is of wholly local concern, the approach has the crucial benefit of avoiding preemption entirely. Wal-Mart's failed attempt to place a Supercenter in Inglewood, California-Wal-Mart's first Supercenter defeat-caused company executives to rethink expansion strategies and is perhaps the paradigmatic successful site fight. ${ }^{96}$

The Los Angeles Alliance for a New Economy (LAANE), a worker advocacy group, first uncovered Wal-Mart's plans to open a Supercenter in the African American community of In-

90. George Lefcoe, The Regulation of Superstores: The Legality of Zoning Ordinances Emerging from the Skirmishes Between Wal-Mart and the United Food and Commercial Workers, 58 ARK. L. REV. 833, 833 (2006).

91. Kris Hudson, States Target Big-Box Stores, WaLL ST. J., June 29, 2007, at A8.

92. Patricia E. Salkin, Supersizing Small Town America: Using Regionalism to Right-Size Big Box Retail, 6 VT. J. ENVTL. L. 48, 54-55 (2005).

93. Lefcoe, supra note 90 , at 842 .

94. Id. at 845 .

95. See, e.g., Cummings, supra note 38, at 1960.

96. See id. at 1975-76 ("[In] the aftermath of the Inglewood fight ... WalMart has placed less emphasis on targeting Superstore development in major cities . . . focusing on the international market . . . [and] small domestic cities."); CEO Aims to Repair Wal-Mart Name, L.A. TIMES, Sept. 9, 2004, at C5 ("We have got to eliminate this constant barrage of negatives that cause people . . . to wonder if Wal-Mart will be allowed to grow,' said [CEO] Scott."); Jessica Garrison et al., Wal-Mart to Push Southland Agenda, L.A. TIMES, Apr. 8,2004 , at B1. 
glewood in March 2002.97 Joining with the United Food and Commercial Workers (UFCW) and community, faith, and political leaders, ${ }^{98}$ LAANE successfully lobbied the city council to enact an emergency ordinance banning "retail stores larger than 155,000 square feet that sold more than 20,000 nontaxable items, such as food," effectively barring the company from Inglewood. ${ }^{99}$ But faced with Wal-Mart's threats to both challenge the ordinance in court and force a repeal referendum, the council quickly overturned it. 100 Fighting back, UFCW successfully pushed a slate of anti-Wal-Mart candidates onto the council in hopes of reenacting the ban. ${ }^{101}$ In response, Wal-Mart formed a front group to organize a ballot initiative allowing construction of a Supercenter and Sam's Club while bypassing the standard city review and approval processes. ${ }^{102}$ Faced with this concrete challenge, Inglewood's anti-Wal-Mart actors coalesced to create the Coalition for a Better Inglewood (CBI), securing endorsements and garnering opposition to the measure through media outreach, community meetings, and door-todoor canvassing. ${ }^{103} \mathrm{CBI}$ branded the measure an "illegitimate power grab" that freed Wal-Mart to ignore the standard legal process; ${ }^{104}$ the appeal worked, as voters defeated the initiative by a wide margin. 105

The site fight's success spread beyond Inglewood.106 Despite these victories, some observers caution that the approach

97. Cummings, supra note 38 , at 1957.

98. Id. at $1957,1960$.

99. Id. at 1958.

100. Id.

101. Id. at $1958-59$.

102. Id. at 1959; Nancy Cleeland \& Abigail Goldman, Wal-Mart Trying to Put Plan on Ballot; The Retailer Is Seeking Approval for a New Store in Inglewood from the City's Voters, Not Its Council Members, L.A. TIMES, Aug. 30, 2003, at A1; see also Initiative Measure to Be Submitted to the Voters (Measure 04-A) § 12-2001.1 G.8 ("The Home Stretch Specific Plan is a comprehensive, stand alone planning document that preempts and replaces all of the standards, criteria, [and] procedures for review . . .."), available at http://www .cityofinglewood.org/pdfs/Home\%20Page/doc.pdf; Measure 04-A § 12-200.1.B.

103. Cummings, supra note 38 , at $1960-63$.

104. Id. at 1962 .

105. Sarah Lin \& Monte Morin, Voters in Inglewood Turn Away Wal-Mart, L.A. TIMES, Apr. 7, 2004, at A1 ("With all votes counted Tuesday evening, 4,575 Inglewood residents had voted in favor of Wal-Mart's plan, while 7,049 had voted against it.").

106. See, e.g., Michael Barbaro \& Steven Greenhouse, Wal-Mart Chief Writes Off New York, N.Y. TIMES, Mar. 28, 2007, at C1 ("Frustrated by a bruising, and so far unsuccessful battle to open its first discount store in the na- 
is not immune to legal challenges based on doubts about whether local land-use decisions can be designed to address labor market concerns rather than traffic flow or other traditional zoning issues. ${ }^{107}$ Others question the longevity of a "reactive, case-by-case" tactic that requires a diverse cast of actors allied in every corner of the nation. ${ }^{108}$ Professor Scott Cummings, who studied the Inglewood campaign in detail, describes how what began as a labor cause quickly required land-use and environmental experts, resulting in an unconventional, "fragile alliance."109 Correspondingly, participants' motivations ranged widely, from the purely political, to fears the company would pollute, to beliefs the land could be better used, to hopes that the fight would energize a wave of community action. ${ }^{110}$

In one respect this interdisciplinary character represents a stirring new approach to labor activism, broadening arguments and tactics without sacrificing the core end of preventing further degradation of working conditions for low-end service workers. ${ }^{111}$ In another respect, however, it represents a startling redirection, sublimating basic issues of dignity and justice for zoning. When the struggle for wages, health care, and unions is abstracted, something the site fight prompts, there may be civic consequences.

\section{PREEMPTION'S DELETERIOUS EFFECTS ON CIVIC DEMOCRACY}

The possibility that some fair-share legislation may survive preemption challenges and the success of some site fights offer hope that local activism can continue and even flourish. But when preemption forces activism around low-wage work and access to health care into the side streets of land-use law and the complexities of working around ERISA, it produces both civic-democratic and legal consequences beyond the immediate success or failure of the particular legislative campaign. To date, no state other than Maryland has enacted a big-box-

tion's largest city, Wal-Mart's chief executive said yesterday, 'I don't care if we are ever here."').

107. Lefcoe, supra note 90, at 833.

108. Cummings, supra note 38, at 1997 ("[T] he large number of separate jurisdictions gives Wal-Mart many potential targets, [so] the site fight strategy could easily be stretched too thin.").

109. Id. at 1989.

110. Id. at 1989-90.

111. Professor Cummings suggests that the site fight "represents an important part of 'next wave' labor activism." Id. at 1978. 
specific minimum labor standards law, though some have tried. ${ }^{112}$ The federal court decision holding the Maryland law preempted establishes both a legal and a civic roadblock. ${ }^{113}$ Preemption's potential to abruptly obliterate months or even years of successful local political activism through a judicial rationale the average person would probably find perplexing may have real democratic reverberations. As we explain below, preemption both derails democracy and deforms democracy.

\section{A. Democracy Derailed: PreEmption AND the Maryland FAIR SHARE ACT}

Sociologists and political theorists have observed that democratic activism is not the natural disposition of the body politic. ${ }^{114}$ Rather, it is culturally created. ${ }^{115} \mathrm{~A}$ fertile culture for civic activism is one where persons become enveloped in social networks that cogently articulate the interactions between private and public problems. ${ }^{116}$ There, space is created for new identities and solidarities mobilized to voice grievances in the public square through the political process. ${ }^{117}$ The organizations and associations that dot America's cities and towns often formalize such networks, providing both the training ground and engine of civic activism, making politics a lived experience. ${ }^{118}$ As Alexis de Tocqueville observed, involvement in local organizations provides Americans "an infinite number of occasions for the citizens to act together... so that every day they should feel that they depended on one another."119

112. See Hudson, supra note 91 (citing AFL-CIO efforts to replicate the Maryland law in three dozen states).

113. Retail Indus. Leaders Ass'n v. Fielder, 475 F.3d 180 (4th Cir. 2007).

114. RICHARD L. WOOD, FAITH IN ACTION 264 (2002) (citing NINA ELIASOPH, AvoIding Politics: How AMERICANs PRODUCE APATHY IN EVERYdAY LIFE (1998)).

115. Id.

116. See HARry C. BOYTE, THE BACKYARD REVOLUTION 196 (1980).

117. ROMAND COLEs, BEYOND GATED POLITICS 218 (2005).

118. See Michael S. Joyce \& William A. Schambra, A New Civic Life, in PETER L. BERGER \& RICHARD JOHN NEuHAus, TO EMPOWER PEOPLE: FROM STATE TO CIVIL SocIETY 12 (Michael Nowak ed., 2d ed. 1996) ("Through these small, local, 'human-scale' associations, Americans not only achieved a sense of belonging and connectedness but also tackled the full range of social and human problems that today have largely become the province of government.").

119. Id. at 13; see also ALEXIS DE TOCQUEVILLE, DEMOCRACY IN AMERICA 513-17 (J.P. Mayer ed., Anchor 1969) (1835). 
But if democratic activism is culturally mediated, democratic apathy may be as well. Among the factors contributing to a decline of American civic life we would include the possibility of preemption of state law alongside the usual culprits, which generally include a dearth of social capital, weakened political institutions, and "the inculcation of democratic skills in ways skewed by socioeconomic inequality, racial/ethnic identity, and gender."120 Preemption disempowers local government, and with that loss of power goes loss of a reason for citizens to participate in civic life.

Indeed, community organizers have long recognized that groups, associations, and other community efforts may attack "problems," things that are difficult or impossible to change, or they may attack "issues," where change is possible or realistic. ${ }^{121}$ Explains Ed Chambers, Executive Director of the Industrial Areas Foundations (IAF), which is the largest community organizing network in the nation: "The sale and consumption of illegal drugs is a problem; tearing down six specifically identified crack houses in a neighborhood is an issue .... Effective actions target issues, not problems." 122 What Chambers intimates and what other seasoned organizers understand is that where victories are or seem possible, activism can flourish. And where victories are or seem impossible, activism can wilt. ${ }^{123} \mathrm{~A}$ group's belief in its ability to effect change can lead its members to action and vice versa. ${ }^{124}$ A 1997 study in Science, for example, reported a strong link between a community's sense that its members had the "collective efficacy" or group power to affect public safety and reduced levels of violence. ${ }^{125}$ While every neighborhood desired a safe environment, only in neighborhoods where residents believed they could influence interpersonal crime did they actually do so. ${ }^{126}$

120. WooD, supra note 114 , at 16 (providing additional citations for each of the categories).

121. EDWARD T. CHAMBERS, ROOTS For RADICALS 84 (2006).

122. Id.

123. WooD, supra note 114, at 202.

124. Robert J. Sampson et al., Neighborhoods and Violent Crime: A Multilevel Study of Collective Efficacy, 277 SCIENCE 918, 918 (1997).

125. Id. (comparing only poor neighborhoods and controlling for individuallevel characteristics and prior violence).

126. Id. (suggesting that "neighborhoods differentially activate informal social controls" that may discourage violence, such as monitoring children's spontaneous playgroups, intervening before teenagers engage in truancy, and confronting those who are disturbing public spaces). 
Further, Robert Putnam's studies of civic engagement suggest that tangible accomplishments are important for associational sustainability because victories evolve into stories of collective triumph, which, in turn, foment intragroup connections and ultimately catalyze activism. ${ }^{127}$ At UPS, where the Teamsters union's civic practices foster "dense and cooperative connections among the employees,"128 workers successfully navigate the immensely difficult holiday package rush by motivating each other with "folklore" of Christmases past, where UPS workers outpaced the competition against incredible obstacles. ${ }^{129}$ Such triumph stories spark a powerful unity, exemplified at UPS by the Teamsters' victorious 1997 strike. ${ }^{130}$ The stories may also eventually spur communities to view activism normatively, instilling a collective belief that, together, anything is possible: "The visible and active presence of a remarkable number of people who think it's possible to do things ... convinces others that it is possible, desirable, and even expected that they, too, will participate and accomplish something." 131

The Maryland Fair Share Act, as enacted, might have elicited the kind of faith in the power of civic engagement that Putnam lauded. Wal-Mart's inadequate health benefits proved to be a conquerable "issue," a stirring tale of "collective triumph" that activists might have drawn on in future fights. A sense of "collective efficacy" might have seeped into Maryland communities. Preemption of Maryland's Fair Share Act, however, cut off that process. Preemption rendered Wal-Mart's poor health benefits a "problem," not an "issue." In place of collective efficacy there is more likely to be collective confusion: Why could Maryland not legislate to address the problem of lowwage work and affordable health care? Why does a federal law that provides no benefits itself deprive a state of the power to do so?

127. See PUTNAM \& FELDSTEIN, supra note 26, at 284 .

128. Id. at 216 .

129. Id. at 211 .

130. See id. at 217-18 (noting that the 1997 Teamsters strike cost UPS $\$ 750$ million); Steven Greenhouse, Yearlong Effort Key to Success for Teamsters, N.Y. TIMES, Aug. 25, 1997, at A1 ("[T] he teamsters[ won] most of what they sought in their 15-day strike against U.P.S. It was labor's biggest victory in years ....”).

131. PUTNAM \& FELDSTEIN, supra note 26, at 255-56 (internal quotation marks omitted). 
Political philosopher Michael Sandel fears civic apathy because it generates a "storyless condition" of extreme disempowerment, a book of empty narratives without "continuity between present and past, and therefore no responsibility, and therefore no possibility of acting together."132 The Maryland experience of activism arguably generated something worse. A distinct narrative was indeed set: local triumph destroyed. And in this tale, while only a legal expert might prove capable of explaining the ending, activists could surely internalize the moral "why even bother?"133

Preemption's neutralization of Maryland's minimumstandards approach is thus a portrait of local democracy derailed. Maryland residents concerned about Wal-Mart's health benefits are now left with two options: organize at the more conservative federal level where their power is weakest, 134 or pressure Wal-Mart to make changes voluntarily. 135 Either option could potentially implicate civic practices, from writing a letter to a U.S. Senator in favor of pro-worker legislation to signing a petition to Wal-Mart's CEO urging workplace changes. But writing a letter to Congress or to Wal-Mart executives is a solitary act, and the sort of gesture that is often perceived as futile. It is no substitute for participation in effective self-governance.

Indeed, as political philosopher Sheldon Wolin has commented, democracy's true power resides not in the halls of Congress or a corporate boardroom but "in the multiplicity of modest sites dispersed among local governments and institutions under local control .... and in the ingenuity of ordinary people in inventing temporary forms to meet their needs." 136 Such

132. SANDEL, supra note 34 , at 351.

133. Cf. WooD, supra note 114 , at 131 ("[P]ublic life must be regularly reenacted by groups drawing on social capital and democratic skills to project democratic power; otherwise, public life withers.").

134. See Cummings, supra note 38, at 1942 (suggesting that progressive activists have deemphasized advocacy at the federal level because it is often more conservative than the local level, where politicians can be more easily influenced and where low-wage workers represent an important constituency).

135. See, e.g., Rathke, supra note 10, at 270-73 (arguing that unionization at Wal-Mart cannot succeed, thus the best hope for improving working conditions is to create a Wal-Mart worker "association" armed with pressure tactics and a "potent public-policy voice"); KATHERINE V.W. STONE, FROM WIDGETS TO Digits: EMPLOYMENT REGULATION FOR THE CHANGING WORKPLACE 230-31 (2004) (advocating "citizen unionism," which pressures employers to voluntarily improve working conditions).

136. Sheldon Wolin, Politics AND Vision 603 (2004). Wolin terms this 
"temporary forms" catalyze and nurture creative civic practices locally, and to shunt this entire category of local practices aside is to circumscribe democracy, molding it into a more "settled system" by repressing its potential as an "ephemeral phenomenon ... embracing a wide range of possible forms and mutations." 137 Yet that is preemption's oft-overlooked effect, permitting two forms of democratic change-federal and voluntaryto trump the local form that might best "generate and continuously renew direct political experience."138

\section{B. Democracy Deformed: PreEmPtion AND the Inglewood SiTE Fight}

Site fights do offer the opportunity for civic engagement with local government that Wolin describes. Yet, the usual topics of land-use planning - square footage, sign size and placement, traffic flow-are far removed from the issues that spark most anti-Wal-Mart activism: wages and health benefits. The most effective organizing is rooted in issues that have direct, identifiable significance in participants' lives, rather than issues developed top-down by strategists after surveying the political or legal landscape. ${ }^{139}$ For example, the IAF's organizing is rooted not around what is rhetorically, tactically, or politically convenient but around the specific frustration that animates a neighborhood (for instance, an abandoned building) as elicited though what the group calls "relational meetings." 140 IAF groups emerge publicly only once such frustrations have been identified, typically after two to three years of meetings between organizers and neighborhood residents. ${ }^{141}$ Writes Chambers, "You don't pick targets and mobilize first; you connect people in and around their interests." 142 Shared interests, not a contrived political strategy, are the point of entry for people to engage in civic democracy and public life. ${ }^{143}$

Site fights do not fit this paradigm well. The zoning issues bound up in such campaigns are but convenient proxies for

\footnotetext{
"fugitive" democracy. Id. at 602.

137. Id.

138. Id. at 604 .

139. See MARK R. WARREN, Dry Bones RATTLING 51 (2001).

140. CHAMBERS, supra note 121, at 50-53.

141. See id. at 48 ("In bringing the United Power organization to birth in metropolitan Chicago from 1995 to 1997, the organizers and initial leaders conducted 9,000 to 9,500 relational meetings over two years ....").

142. Id. at 46 .

143. Id. at 50 .
} 
health care and labor rights concerns. Surely some site-fight actors experience a "cold anger" 144 over declining community aesthetics and for them zoning concerns are legitimately central. ${ }^{145}$ But for most, preventing the "Wal-Martization"146 of the economy by denying Wal-Mart the power to dictate labor standards is the true concern and motivator. Imagine Wal-Mart's lowest paid employees earned $\$ 20$ per hour with free health, dental, and vision benefits and a retirement plan. Would WalMart's proposed entry into New York, Chicago, or Southern California provoke the same level of fierce resistance? Would there be any resistance? For community members concerned about wages and health care, the fears Wal-Mart provokes are reformulated, redirected, and repackaged by the site-fight strategy.

To see such sublimation in action one need look only to Inglewood. There, the first strike against Wal-Mart's encroachment was for LAANE and UFCW-worker advocacy groups-to lobby for an emergency land ordinance. ${ }^{147}$ The battle would ultimately pivot on the merits of Wal-Mart's oversized zoning initiative, which anti-Wal-Mart advocates defeated on the strength of a procedural fairness-not labor-message. ${ }^{148}$ While union density, low wages versus low prices, and other worker-centered arguments played campaign roles, on election day such issues were relegated to the level of white noise. This vote was primarily about a building permit, not workers' rights. ${ }^{149}$ Indeed, the day before the vote, LAANE's executive

144. Id. at 108. See MARY BETH Rogers, COLD ANGER 10 (1990) (describing the anger of the working poor and their attempts at political intervention).

145. See generally ANDREs DuANY ET AL., Suburban NATION: THE Rise OF SPRAWL AND THE DECLINE OF THE AMERICAN DREAM (2000) (describing the aesthetic consequences of unregulated urban growth); ANTHONY FLINT, THIS LAND: THE BATTLE OVER SPRAWL AND THE FUTURE OF AMERICA (2006).

146. See Editorial, supra note 28 ("This Wal-Martization of the work force, to which other low-cost, low-pay stores also contribute, threatens to push many Americans into poverty.").

147. See Lin \& Morin, supra note 105; LAANE, A New Vision for Economic Fairness, http://www.laane.org/about.html (last visited Apr. 18, 2008).

148. See Lin \& Morin, supra note 105.

149. See id. ("The expansion encountered fierce opposition from organized labor, which insisted that Wal-Mart's aggressive business practices and antiunion employment policies would result in lost jobs and depressed wages for millions of workers. ... The question on Tuesday's ballot in Inglewood was whether to allow the retailer to obtain building permits without a public hearing or environmental impact study. Many community leaders and Inglewood city officials, except the mayor, said the measure would set a dangerous 
director, Madeline Janis-Aparicio, stressed the crucial importance of the outcome, but for reasons that might seem surprising for an organization devoted to economic, not property, justice150: "The stakes in Inglewood are the highest they have ever been anywhere. They want to throw out all the local planning laws and make themselves a little Wal-Mart city."151 JanisAparicio referenced labor issues only tangentially, characteristic of the doom associated with a Wal-Mart-controlled enclave. ${ }^{152}$ Her true emphasis was land use.

Thus, while the land-use approach can be effective, ${ }^{153}$ the strategy also imparts a clear cost. The particular interests that might animate a community opposed to Wal-Mart seem likely to be fears of low wages, inadequate health care, or any number of other issues related to the company, yet the site fight plows the way for just one: land use. By artificially and unilaterally manufacturing this shared interest, the site fight serves as a one-size-fits-all funneling mechanism that turns the fundamental IAF insight-that organizing issues are best generated bottom-up based on interests, not top-down based on strategy-on its head, leaving the foundation for democratic action less sturdy and less likely to spark sustained activist responses. ${ }^{154}$

Then again, some social theorists argue that in some circumstances self-fulfillment can actually enable political and group commitments. ${ }^{155}$ Further, they argue that purely personal investments in an organization do not necessarily sap its collective strength. ${ }^{156}$ Sociologist Paul Lichterman calls this "personalism" and cites twelve-step addiction groups ${ }^{157}$ and some

precedent for cities nationwide by preempting local control over development process and circumventing environmental review of large projects.").

150. See LAANE: Building a City of Justice, http://www.laane.org (last visited Apr. 18, 2008) ("At LAANE, we are committed to building a new economy that restores the American dream of fair wages and benefits in return for hard work.").

151. Garrison \& Lin, supra note 1.

152. See id.

153. Harold Meyerson, Wal-Mart Comes North, AM. ProsPeCT, Apr. 2007, at 28, 29 ("[C]ity councils across California and Oregon, New York and New England have enacted big-box ordinances blocking Wal-Mart from moving into their jurisdictions.").

154. See CHAMBERS, supra note 121, at 108 ("Effective public-life organizers and leaders feel that anger, listen to it, and act on it.").

155. PAul Lichterman, The SEARCh For Political Community 4 (1996).

156. Id. at 10 ("Certainly members of a community may be 'personally' invested in it: their feelings are an important part of their sense of communal belonging.").

157. Id. at 8 . 
small political organizations as examples of the phenomenon where members bring deeply individualized motivations to bear on public commitments toward a common good.158 But Lichterman readily acknowledges studies by Robert Bellah and others suggesting that if personal motivations cannot be defined "in terms of communal obligations, then those commitments would have a precarious basis, and might not last long ... only to reemerge in some other short-lived personal enthusiasm." 159

The site fight might be like some of the small political or twelve-step groups Lichterman studied, where a variety of purely personal motivations can be defined in terms of the collective, thereby enhancing group-helping behavior. It seems more likely, however, that when labor activists join with a group whose stated purpose is zoning, at times enough energy might be generated for victory (zoning is, after all, still connected to the group's broader labor sentiments because it can exclude Wal-Mart), the strength and stability of the collective is ultimately weakened by the precariousness of the alliance. For if the key to melding disparate energies for collective gain is the group's ability to tie those energies to something communal, the causes of "No to Wal-Mart!" or "Workers' Rights!" seem like better candidates than any particular zoning ordinance or referendum. The site fight's technical and idiosyncratic nature unhelpfully sidetracks and attenuates the commonalities between activists' personal motivations in a way that may be strategically, but not civically, logical.

Indeed, the more challenging the task of relating a group's scattered, diverse personal interests to the communal goal in question, the harder it may be to maintain the organization. Where the stated group aim is detached from on-the-ground passions, civic activism may degrade into "impulsive protest"160 with participants concerned more with "cultural expressiveness" 161 than true alliance. A culturally salient entity like WalMart might then draw many to a site fight because it seems like the trendy thing to do. ${ }^{162}$ Some would rightly question the

158. Id. at $4-5$.

159. Id. at 13-14 (citing ROBERT BELLAH ET AL., HABITS OF THE HEART 133 (1985)).

160. LICHTERMAN, supra note 155, at 13.

161. WOLIN, supra note 136 , at 584 .

162. See generally MALCOLM GladWell, The TIPPING PoINT 7 (2004) (tracing the phenomena of social epidemics, which draw people to products, messages, and movements). 
genuineness and sustainability of a democratic activism founded on fad. 163

Moreover, from Wal-Mart's perspective, that the site fight reorients grassroots challenges from labor issues to more technical and less intuitive land-use issues is probably desirable. Wal-Mart's image largely depends not on the aesthetics of its stores but on the public's affirmation that the benefits of low prices trump the detriments of low wages. 164 The less the company is forced to defend its labor practices directly, or to focus on the harms it causes to the local economy, the better. ${ }^{165}$

In reality, the contours of the anti-Wal-Mart argument have been a part of the American political debate for decades; progressives have long fought for policies that promoted mass purchasing power. ${ }^{166}$ What is new, however, is the shift in how the argument is framed and operates, from labor to land. In consequence, Wal-Mart, a soft target for moral-economic critiques as an unrivaled labor and employment villain in a swelling sea of populist sentiment, ${ }^{167}$ remains insulated from such potent attacks as the site fight intrudes, reorients, and obscures the high-wage, low-price cause.

Of course, on its own Wal-Mart is no stranger to the art of rhetorical deflection, embedding serious debate over its harsh labor policies within homemade, folksy euphemisms. ${ }^{168}$ At-will, part-time, low-wage clerks are company "associates" who face not discipline but "coach[ing]," not from the foreman or from Human Resources, but from the "people division." 169 At the

163. See LICHTERMAN, supra note 155, at 14 ("How could others depend on someone who tied political commitments to personal preference instead of a sense of obligation?"); $c f$. WOLIN, supra note 136, at 603 ("[Democracy] should be conceived of as a moment of experience, a crystallized response to deeply felt grievances or needs . . . . Its moment is not just a measure of fleeting time but an action that protests actualities and reveals possibilities.").

164. See, e.g., Wal-Mart President \& CEO Lee Scott, Advertisement, WalMart's Impact on Society: A Key Moment in Time for American Capitalism, N.Y. REV. BoOKS, Apr. 7, 2005, at 6.

165. See id.

166. Meg JACobs, Pocketbook Politics 5-7 (2005); Lichtenstein, supra note 27 , at 26 .

167. See Robin Toner, A New Populism Spurs Democrats on the Economy, N.Y. TIMES, July 16, 2007, at A1 ("[T] he latest populist resurgence is deeply rooted in a view that current economic conditions are difficult and deteriorating for many people.").

168. See Lichtenstein, supra note 27, at 17 ("Walton strove mightily, and often successfully, to project Wal-Mart as the embodiment of a more virtuous and earthy enterprise.").

169. Id. 
company's annual meeting, top executives perform vaudevillelike skits and songs that self-mock and embarrass. ${ }^{170}$ Professor Nelson Lichtenstein has remarked on the "carnivalesque" quality of this culture, which allows Wal-Mart to portray itself as a Main Street merchant with small-town values while pursuing ruthless labor policies that give it the efficiencies of a huge corporation. ${ }^{171} \mathrm{We}$ argue that site fights themselves take on similarly carnivalesque qualities when they explicitly oppose WalMart yet implicitly abet the company's avoidance of allegations of employee abuse by shifting debate to an alternative (and arguably safer) terrain.

That is unfortunate. As historian Michael Kazin has suggested, progressivism's strength has traditionally depended upon a people united less by the prices and characteristics of "what they wish to consume" and more by their willingness to empathize with producers and project their grievances. ${ }^{172}$ In the 1930s, for example, an ideological alignment between workers and consumers "transformed their agenda of mass purchasing power into a program of national recovery." 173 But where repeated challenges to the nation's largest and most regressive employer abstract core producer grievances into something else, progressivism's potential for renewal dissipates. Consequently, alongside the fear that "management of the common good is being ceded" to corporate powers ${ }^{174}$ stands another fear: that, in the United States, management of progressivism is being ceded to the powers of preemption.

\section{CIVIC DEMOCRACY AS A LEGAL ARGUMENT AGAINST PREEMPTION}

In Part II.A above, we described a legal argument that ERISA does not preempt fair-share laws. Here, we move beyond that conventional form of technical argument about the scope of preemption to offer a novel, fundamental, and normative argument against broad preemption. The legal debate over the scope of federal preemption of state laws usually focuses on two competing constellations of values. On the one hand, the benefits of national uniformity are said to favor preemption.

170. See id. at $17-18$.

171. See id.; see also Mark Gimein, Sam Walton Made Us a Promise, FoRTUNE, Mar. 18, 2002, at 120, 121-22.

172. See KAZIN, supra note 2 , at 286 .

173. JACOBS, supra note 166, at 9.

174. Wolin, supra note 136, at 578. 
This was the policy argument that carried the day in the Fourth Circuit's analysis of the Maryland fair-share case. ${ }^{175}$ On the other, the benefits of local experimentation and local control are said to argue against preemption. ${ }^{176}$ As applied to local efforts to regulate low wages and poor health benefits, the argument is almost always phrased as pitting the benefits to WalMart of enabling it to have one uniform benefit plan, one uniform wage scheme, and even one uniform human relations policy, against the benefits of allowing local governments to experiment with solutions to the health care crisis. 177

This phrasing of the competing arguments underlying preemption law misses two crucial values. First, states retain regulatory power in many areas. Federal preemption does not liberate a nationwide business from complying with local law; it simply limits the types of local laws that apply. Although the Fourth Circuit majority found ERISA to preempt Maryland law because it discerned in the statute a policy against requiring employers to "navigat[e] the narrow regulatory channel between" state law and ERISA's regulatory scheme, ${ }^{178}$ that navigation is necessary for any nationwide business. Wal-Mart still must confront local land-use law, local variations in taxes, and local variations in employment laws. It must pay a higher minimum wage in the thirty states that have minimum wages higher than that of the FLSA. ${ }^{179}$ It cannot discriminate in employment on the basis of sexual orientation or political activity in California; 180 but it is free to do so in most other states. It must comply with different states' regulation of the business of insurance, as well as disability and unemployment insurance

175. See Retail Indus. Leaders Ass'n v. Fielder, 475 F.3d 180, 197 (4th Cir. 2007).

176. See, e.g., ERWIN Chemerinsky, Constitutional LAW: PRINCIPLeS AND POLICIES 390-96 (3d ed. 2006) (describing the basic policy issues in preemption analysis). Some scholars defend preemption even with a strong commitment to federalism. E.g., Viet D. Dinh, Reassessing the Law of Preemption, 88 GEO. L.J. 2085, 2087 (2000); Caleb Nelson, Preemption, 86 VA. L. REV. 225, 230-32 (2000).

177. See Zelinsky, supra note 5, at 848; Edward A. Zelinsky, The New Massachusetts Health Law: Preemption and Experimentation, 49 WM. \& MARY L. REV. 229, 280-81 (2007) [hereinafter Zelinsky, Massachusetts]; Sharon Reece, ERISA Preemption and Fair-Share Legislation, 4-6, Aug. 9, 2007, available at http://ssrn.com/abstract=1006026.

178. Fielder, 475 F.3d at 197.

179. See U.S. DeP'T OF Labor, Minimum Wage LaWs In the States (Jan. 1, 2008), available at http://www.dol.gov/esa/minwage/America.htm.

180. See CAL. LAB. CODE $\S \S 1101-02$ (West 2007). 
laws and mandatory leave policies. All of these require an employer to consider health benefit plan design. It must adhere to different tax withholding schemes. It pays different forms of sales tax, property tax, and other taxes. The most that ERISA preemption can do is to channel the fight against Wal-Mart's labor practices into areas where local law remains enforceable (such as land use, taxes, and wages) and away from areas where local law cannot operate (direct regulation of health benefits and unionization). It does not free Wal-Mart from local legal efforts aimed at changing its practices.

Second, to the extent that preemption does not channel but instead chokes off avenues of legal challenge, preemption stifles local political organizing around issues such as affordable health care and living wages. When labor activists, community organizers, people of faith concerned about poverty, and health care activists are told by their lawyers that organizing is futile because federal law denies their local government the power to enact law to address key issues, it is as if the government is telling people that democracy is not for them. Preemption, in effect, functions as a form of repression. It tells citizens that it is pointless to organize politically at the local level and engage in democratic action to create a better society because all power is held by a seemingly remote federal authority. Indeed, local activists are keenly aware that they lack the economic and political power to persuade a majority of the House and Senate to enact comprehensive legislation on wages and health care. Surely, a federal court ought to think very carefully before it reads an ambiguous, hastily considered, and poorly drafted provision like the ERISA preemption clause as a directive to silence local organizing around the issue of health care.

There is currently a debate among legal scholars about whether broad preemption of state law is beyond the scope of Congress's constitutional powers. ${ }^{181}$ During debates over New Deal and Great Society social programs, and fights over civil rights legislation, progressives often argued in favor of broad federal legislative power and broad preemption of regressive state laws, and conservative defenders of business prerogatives often defended a robust vision of states' rights and limits on federal legislative action. ${ }^{182}$ Today the roles are often reversed,

181. See CHEMERINSKY, supra note 176, at 390-96; Dinh, supra note 176 , at 2087; Nelson, supra note 176, at 228-31.

182. See William N. Eskridge, Jr., Some Effects of Identity-Based Social Movements on Constitutional Law in the Twentieth Century, 100 MICH. L. REV. 
with progressives arguing for the right of states to regulate and conservatives arguing for federal preemption of state law. When the debate focuses on the power of Congress to preempt state law, progressives now sometimes argue for the presumption against preemption that conservatives used to favor, and vice versa. ${ }^{183}$

Our analysis has implications for this debate but does not require one to reject the power of Congress to preempt state law. In our view, Congress could enact a statute preempting all state and local laws on the subject of health care, but Congress has not done so in ERISA. ERISA was enacted to deal with a specific problem of the 1960s and 1970s-widespread pension plan defaults-and was premised on the assumption that health benefits plans were financially and socially insignificant in comparison to pension plans. ${ }^{184}$ Thus, ERISA extensively regulates pension plans to protect employees but says almost nothing on the content of health plans. ${ }^{185}$ Broad preemption of state regulation of pension plans makes sense in light of the extensive federal regulation; preemption of health benefits was almost an afterthought. There is no reason to read, more broadly than is necessary to effectuate congressional intent, the "relates to" language of section 514 as reflecting a deliberate congressional judgment to completely disempower states and local governments from addressing health care costs and availability. That is to say, while Congress clearly made a decision to protect employer-provided benefits plans from some state regulation, it is not clear how much regulation was to be displaced. It is only by abstracting several degrees from what Congress actually considered in 1974 that we can conclude that Congress intended to prevent state and local experimentation with measures to solve the contemporary crisis in health care finance. Courts should not conclude that a statute meant to address the problem of pension plan defaults should silence one of the great political debates of our era: the debate over the value of labor in the low-wage retail sector.

In short, given the drastic political and social consequences of preemption, courts ought not read the preemption provision

2062, 2115-16 (2002).

183. Cf. Nelson, supra note 176 , at 229 ("In recent years . . liberal advocates of government regulation have joined in arguing that current tests for preemption risk displacing too much state law.”).

184. Cf. 29 U.S.C. $§ 1001$ (2000) (focusing on pension plans in declaration of policy).

185. See 29 U.S.C. $\S \S 1001-1461$. 
broadly in an area where Congress chose not to regulate. Since in ERISA Congress chose not to regulate health benefits, and particularly the unavailability of health care to low-wage workers, courts ought not conclude that Congress's failure to regulate operates to displace state and local laws in this area of intense local concern.

The question for courts confronting preemption challenges is to decide whether the structure and purpose of ERISA and federal health care policy are consistent with these sorts of state and local innovations. As we have shown, neither the language of ERISA nor the governing Supreme Court precedent compel preemption of state and local fair-share laws. At the level of policy, therefore, courts confront a choice. Is ERISA preemption of fair-share legislation consistent with ERISA policy or not? To answer this question, courts should move beyond the usual preemption policy arguments about the benefits of national uniformity and the desirability of local experimentation in the area of health care finance reform. Courts can more profitably focus on whether state and local communities, and the governments that respond to their pressure, should be empowered to address through legislation what they conceive as social problems.

An argument often made in favor of ERISA preemption of state and local fair-share laws is that such laws are bad policy because they will drive up prices and thus hurt the very group of people they are intended to help: those earning low wages. ${ }^{186}$ Others dispute this. ${ }^{187}$ The effect of wage regulation and health care finance regulation on prices, on levels of employment, and on aggregate wealth among low-income groups is obviously an empirical question. It is a question on which economists differ. ${ }^{188}$ Given that reasonable minds differ, the important question is who should decide. Preemption of state and local laws means that Congress alone decides, and that it will decide without empirical testing of the competing economic models about the effect of excluding Wal-Mart from local economies on prices, employment, and wealth. Moreover, even if state and local fair-share laws do increase prices, reduce employment, and

186. See, e.g., Zelinsky, Massachusetts, supra note 177, at 849.

187. See, e.g., DUBE \& JACOBS, supra note 17, at 8.

188. Some of those opinions are canvassed in the articles in this symposium. See, e.g., David Neumark \& William Wascher, Minimum Wages and Low-Wage Workers: How Well Does Reality Match the Rhetoric?, 92 MinN. L. REV. 1296 passim (2008). 
cause a net aggregate loss of wealth for low-wage workers, that is not a reason for federal law to preempt such law. In a democracy, the local community should be empowered to decide whether they want Wal-Mart-style jobs and Wal-Mart-style shopping. ${ }^{189}$

\section{CONCLUSION}

Across towns, cities, and states, thousands of people organize against Wal-Mart. For these groups, Wal-Mart is an engine driving today's wage and health care inequalities to an historic high. How federal law treats their grassroots efforts is central to the future of the ongoing debate about whether communities are better off with or without Wal-Mart's low prices, bad jobs, and adverse effects on the local retail sector.

Preemption doctrine has served both to derail the debate about Wal-Mart, by invalidating the Maryland fair-share health care reform act that was the result of years of grassroots organizing in Maryland, and to deform it by forcing a debate over working conditions and health care into a debate over land use. But the law of preemption does not compel this result. The anti-Wal-Mart fervor is bottom-up and neighbor to neighbor. The organizing it prompts is eminently democratic. Instead of derailing and deforming democracy, courts should rein in preemption, stand aside, and let the spirit of civic democracyperhaps the very future of progressivism-shine through.

189. For a description of the significance of Wal-Mart as a target for local activism around wages and working conditions in retail sales, see Orly Lobel, Big-Box Benefits: The Targeting of Giants in a National Campaign to Raise Work Conditions, 39 ConN. L. REV. 1685, 1688-94 (2007). 